\title{
Investigation of respiratory disorders in Thoroughbred racehorses training at the Brazilian Jockey Club
}

\author{
Natália Rebouças Pires ${ }^{1}$ Maria Fernanda de Mello Costa ${ }^{2}$ Marcia Torres Ramos ${ }^{3}$ \\ Anna Paula Balesdent Barreira ${ }^{4}$ José Renato Junqueira Borges ${ }^{5}$
}

${ }^{1}$ Faculdade de Veterinária, Universidade Castelo Branco (UCB). Programa de Pós-graduação em Medicina Veterinária - Clínica e Reprodução Animal, Faculdade de Veterinária, Universidade Federal Fluminense (UFF), Rua Vital Brasil Filho, 64, 24230-340, Niterói, RJ, Brasil. E-mail: nreboucas@infolink.com.br. Corresponding author.

${ }^{2}$ CHASP, Waikato Institute of Technology, Hamilton, New Zealand. Programa Mestrado em Diagnóstico Clínico e Laboratorial em Medicina Veterinária, Universidade Severino Sombra (USS), Vassouras, RJ, Brasil.

${ }^{3}$ Instituto de Veterinária, Programa de Pós-graduação em Medicina Veterinária, Universidade Federal Rural do Rio de Janeiro (UFRRJ), Seropédica, RJ, Brasil. Programa Mestrado em Diagnóstico Clínico e Laboratorial em Medicina Veterinária, Universidade Severino Sombra (USS), Vassouras, RJ, Brasil.

${ }^{4}$ Departamento de Medicina e Cirurgia Veterinária, Instituto de Veterinária, Universidade Federal Rural do Rio de Janeiro (UFRRJ), Seropédica, RJ, Brasil.

${ }^{5}$ Faculdade de Agronomia e Medicina Veterinária, Universidade de Brasília (UnB), Brasília, DF, Brasil.

\begin{abstract}
Athletic horses need to maintain healthy airways for optimal performance. This study investigated the presence of respiratory problems in apparently healthy Thoroughbred racehorses in training. According to the Revised Consensus Statement on Inflammatory Airway Diseases of Horses (2016), determining the prevalence of respiratory disorders in different equine populations is fundamental for understanding these diseases. In total, 72 clinically sound Thoroughbred racehorses, in training at the Brazilian Jockey Club (JCB), were initially examined using interpleural pressure measurement by ventigraphy and respiratory endoscopy. When secretions were present in the airways, transendoscopic tracheal aspiration was performed, and the sample was sent for cytology. The main findings included a combination of bronchospasm and tracheal secretions with $61 \%$ of the cytology slides showing neutrophil counts $\geq 20 \%$. Overall, a significant number of the horses displayed signs suggestive of inflammatory airway disease (mild equine asthma), including $47 \%$ with increased DPplmax, $11 \%$ with tracheal mucus accumulation [mucus score (MS) $\geq 2$ ] and 18\% with carina edema. This was more pronounced in 2-year-old horses within the population studied. These findings are consistent with the literature and reinforce the importance of routine respiratory examination of athletic horses. There is a high incidence of subclinical respiratory disorders in Thoroughbred racehorses in training at the JCB and a significant association between tracheal $M S \geq 2$, carina edema, and elevated DPplmax.
\end{abstract}

Key words: subclinical airway inflammation, sports medicine, endoscopy, interpleural pressure, cytology.

Investigação de doenças respiratórias em cavalos de corrida em treinamento no Jockey Club Brasileiro

RESUMO: Cavalos atletas devem apresentar higidez das vias respiratórias para que obtenham bom desempenho esportivo. Este estudo buscou verificar a incidência de alterações respiratórias em cavalos da raça Puro Sangue Inglês (PSI) de corrida em treinamento, aparentemente sadios. De acordo com o Estatuto do Consenso de Doenças Inflamatórias das Vias Aéreas revisado em 2016, o levantamento das alterações respiratórias em diferentes populações de cavalos é fundamental para o entendimento dessas enfermidades. Nesse sentido, foram examinados 72 equinos PSI em treinamento no Jockey Club Brasileiro (JCB), por meio de mensuração da pressão interpleural através da ventigrafia e endoscopia respiratória. Quando presentes nas vias aéreas, foram coletadas secreções por aspirado traqueal transendoscópico para realização de citologia. Os achados prevalentes foram a combinação de broncoespasmo e secreções traqueais onde, em $61 \%$ das lâminas, houve contagem de neutrófilos $\geq 20 \%$. De um modo geral, um percentual significativo de cavalos apresentou sinais sugestivos de Doença Inflamatória das Vias Aéreas (DIVA), incluindo 47\% com elevação na $\Delta$ Pplmax, 11\% com aumento no muco traqueal (score de muco $\geq 2$ ) e $18 \%$ de edema de carina. Dentro da população estudada, essas alterações foram mais pronunciadas em animais de 2 anos. Esses achados reforçam a importância da investigação respiratória rotineira nos cavalos atletas indo ao encontro do que foi descrito em outras publicações. As alterações respiratórias subclínicas têm alta incidência em cavalos PSI em treinamento no JCB e existe uma associação significativa entre o muco traqueal (score $\geq 2$ ), edema de carina, e elevação na DPplmax.

Palavras-chave: inflamação subclínica das vias aéreas, medicina esportiva, endoscopia, pressão interpleural, citologia.

\section{INTRODUCTION}

Optimal airway function is essential for horses performing at high levels. It is common for subclinical respiratory diseases to go undetected on routine clinical examinations, often requiring auxiliary diagnostic methods (WYSOCKA \& KLUCINSKI, 2014). According to COÜETIL et 
al. (2016), Inflammatory Airway Disease-IAD(mild to moderate equine asthma) is a nonseptic inflammation, which can affect horses of any age and is prevalent in racehorses. The diagnosis is based on the presence of clinical signs of lower airway disease (poor performance, cough), documentation of lower airway inflammation based on mucus detected during endoscopy [mucus score $(\mathrm{MS}) \geq 2]$, cytology or abnormal lung function, and the exclusion of severe equine asthma [recurrent airway obstruction (RAO)/heaves] along with infectious and other respiratory diseases. There are indications that the frequent observation of this condition in racehorses may be linked to the innate immune response of equine bronchial epithelial cells that is possibly altered by intense physical exercise (FRELLSTEDT et al., 2015).

A study by HOLCOMBE et al. (2006) indicated that only $4 \%$ of horses with tracheal mucus observed during endoscopy also had nasal discharge, that pulmonary auscultation of horses with tracheal mucus accumulation was often normal, and that coughing was usually absent in these horses. These observations reinforce the importance of respiratory endoscopy as an effective diagnostic method, especially in horses mildly affected by chronic or sub-acute pathologies (BEECH, 1991). Also, a recent study demonstrated that endoscopic assessment of carina thickness and airway mucus is useful for diagnosing IAD and RAO (WYSOCKA \& KLUCINSKI, 2014).

In animals with bronchospasm, there is an increased difference between the lowest inspiratory pressure and the highest expiratory pressure (BOERMA et al., 1995), allowing maximal changes in interpleural pressure $(\triangle \mathrm{P}$ plmax $)$ to be measured under field conditions for the purpose of assessing the severity of bronchospasm (HERHOLZ et al., 2002). This diagnostic method, known as ventigraphy, uses an esophageal balloon attached to the distal end of the catheter with a pressure transducer connected to a physiograph and provides readings for $\Delta \mathrm{Pplmax}$. Absence of bronchospasm is confirmed by the demonstration of values below $4 \mathrm{~cm}$ of $\mathrm{H}_{2} \mathrm{O}$ (KLEIN \& DEEGEN, 1987).

Cytology is a well-described auxiliary diagnostic test for detecting inflammation or infection in the airways. The collection of samples via transendoscopic aspiration has especially proven valuable for racehorses in training because it is minimally invasive and does not require sedation or disruption of the training schedule (KUSANO et al., 2008).
Despite several studies describing cytological and endoscopic profiles of horses with inflammatory airway conditions, to the authors' knowledge there are no studies reporting the incidence of subclinical airway disease in racehorses in training at the Brazilian Jockey Club (JCB), which is notably one of the most important racetracks in Latin America. This study investigated the occurrence of airway disorders in asymptomatic Thoroughbred racehorses training at the $\mathrm{JCB}$, while describing the most common abnormalities and the association between them.

\section{MATERIALS AND METHODS}

In total, 72 clinically sound and actively racing Thoroughbreds were examined during the Brazilian summer and autumn, between the months of February and June. The study population consisted of equal numbers of males and females aged 2-6 years under the care of three trainers at the JCB, Rio de Janeiro. This sample size represented 5\% of all active horses at the JCB during the research period. Horses were selected from a group of 150 animals without the clinical signs of respiratory disease based on history and clinical examination. Tests were performed at the stables where the horses were housed between 8 am and 9 am, 60-90min after morning exercises. Ventigraphy was followed by endoscopy, and when secretions were observed, tracheal samples were collected for cytology. Each examination took 8-10min; the horses were mechanically restrained with a twitch, and the examination was well tolerated. The probe of the ventigraph $\left(\right.$ Ventigraph $^{\circledR}$ ) consisted of a rigid outer covering with a thin internal catheter and a balloon at the end and measured $170 \mathrm{~cm}$ in length and $8 \mathrm{~mm}$ in diameter. It was introduced into the esophagus through the right nostril up to the mediastinum, approximately $135-145 \mathrm{~cm}$ from the nostril, and only then was the balloon tip inflated with $10 \mathrm{~mL}$ of air pushed through a syringe. According to the technique described by KLEIN \& DEEGEN (1984), accurate placement of the probe is confirmed by recording a sequence of 10 regular respiratory cycles. Differences in pressure measured by the balloon were transmitted pneumatically to the ventigraph through the probe and registered graphically on the recording paper provided with the equipment by the manufacturer. The recording paper speed was $2 \mathrm{~mm} / \mathrm{s}$ for $5 \mathrm{~min}$. Interpleural pressure differences $\leq 4 \mathrm{~cm} \mathrm{H}_{2} \mathrm{O}$ were considered as physiological, $5-8 \mathrm{~cm}$ $\mathrm{H}_{2} \mathrm{O}$ as mildly increased, $9-14 \mathrm{~cm} \mathrm{H}_{2} \mathrm{O}$ as moderately 
increased, and $\geq 15 \mathrm{~cm} \mathrm{H}_{2} \mathrm{O}$ as severely increased according to literature (AINSWORTH et al., 2003; PEARSON et al., 2007).

Endoscopic exams were performed by the same veterinarian (NR) with a Pentax flexible fiberscope, model $38 \mathrm{LX}, 170 \mathrm{~cm}$ long, $12.8 \mathrm{~mm}$ diameter, and with a working channel of $3.8 \mathrm{~mm}$. Abnormalities were recorded, with the amount of tracheal mucus being scored subjectively (0-5) according to GERBER et al. (2004). Tracheal septum thickness was evaluated according to WYSOCKA \& KLUCINSKI (2014) and the severity of exerciseinduced pulmonary hemorrhage (EIPH) as described by PASCOE (1981).

Transendoscopic collection of tracheal mucus was achieved by the insertion of a polyethylene tube (ESS Supplies ${ }^{\circledR}$ ) through the equipment's working channel and aspiration of the sample from the caudal portion of the trachea, cranial to the bronchial bifurcation according to the technique described by SWEENEY (1992).

The tracheal samples were placed on glass slides and prepared using the squash technique described by COWELL et al (1992). Slides were immediately labeled, fixed with methanol, stained with Wright-Giemsa, and sent to the Veterinary Anatomic Pathology Laboratory at Universidade Federal Fluminense (UFF) for a differential count of 300 nucleated cells as mentioned in ROBINSON (2003).

Results of the ventigraphy and endoscopy were subjected to statistical analysis with Minitab $^{\circledR}$ 17.3.1 software using the Chi-square test, with a $\mathrm{P} \leq 0.05$ considered statistically significant, to investigate the correlation among increased $\Delta$ Pplmax, tracheal mucus $\geq 2$, and carina edema, and the correlation between tracheal mucus and age. Descriptive statistics were used to assess the incidence of airway disorders in this population of clinically healthy racehorses.

This study was performed according to the ethical standards of the local committee (Colégio Brasileiro de Experimentação Animal - COBEA).

\section{RESULTS AND DISCUSSION}

Based on ventigraphy alone, $47 \%(n=34)$ of the horses examined presented some degree of bronchospasm evidenced by interpleural pressure variations higher than $4 \mathrm{~cm} \mathrm{H}_{2} \mathrm{O}$ (Table 1 ). When only horses with abnormal $\Delta$ Pplmax were considered, $94 \%$ had pressure variations between 5 and $8 \mathrm{~cm}$ $\mathrm{H}_{2} \mathrm{O}$, while only $3 \%$ reached $11 \mathrm{~cm} \mathrm{H}_{2} \mathrm{O}$ (Table 1 ), demonstrating that bronchospasm was predominantly mild. According to COÜETIL et al. (2007 and 2016) mild variation in $\Delta$ Pplmax $\left(5-10 \mathrm{~cm} \mathrm{H}_{2} \mathrm{O}\right)$ could be associated with IAD horses.

When endoscopy alone was considered, $50 \%(n=36)$ of the horses had at least one airway abnormality. From the 36 animals with endoscopic abnormalities, $56 \%(\mathrm{n}=20)$ presented one, $36 \%$ $(n=13)$ presented two, and $8 \%(n=3)$ presented three or more alterations. Presence of tracheal secretions was the main finding in the endoscopy (16/36) followed by pharyngeal lymphoid hyperplasia $(14 / 36)$, carina edema (13/36), EIPH (9/36), dorsal displacement of soft palate (3/36), recurrent laryngeal neuropathy $(1 / 36)$, and epiglottic entrapment (1/36).

When 2-year-old horses were compared to older animals using Chi-square, they had a significantly greater likelihood $\left(\mathrm{P}=0.001, \chi^{2}=11.15\right)$ of presenting a tracheal $\mathrm{MS} \geq 2$ (Table 2). This may be related to the adaptation to intensive training, which has been reported to alter the innate immune response in the lung and the systemic circulation

Table 1 - Ventigraphy results from 72 thoroughbred racehorses in training at the Brazilian Jockey Club, in Rio de Janeiro, according to age.

\begin{tabular}{|c|c|c|c|c|c|c|c|c|c|}
\hline \multirow{2}{*}{$\begin{array}{l}\text { Age } \\
\text { (years) }\end{array}$} & \multirow{2}{*}{$\begin{array}{l}\text { Number of } \\
\text { horses }\end{array}$} & \multirow{2}{*}{$\begin{array}{c}\text { Normal } \Delta \mathrm{Ppl} \\
\leq 4\end{array}$} & \multicolumn{7}{|c|}{ 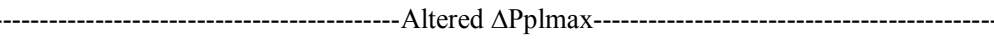 } \\
\hline & & & 5 & 6 & 7 & 8 & 9 & 11 & $\% /$ age \\
\hline 2 & 11 & 3 & 1 & 1 & 5 & - & - & 1 & $72 \%$ \\
\hline 3 & 22 & 12 & 5 & 3 & - & 1 & 1 & - & $45 \%$ \\
\hline 4 & 19 & 12 & 6 & 1 & - & - & - & - & $36 \%$ \\
\hline 5 & 13 & 6 & 1 & 1 & 2 & 3 & - & - & $53 \%$ \\
\hline 6 & 07 & 5 & - & - & 2 & - & - & - & $28 \%$ \\
\hline Total & 72 & 38 & 13 & 6 & 9 & 4 & 1 & 1 & \\
\hline
\end{tabular}


Table 2 - Tracheal secretions score observed in 72 clinical sound thoroughbred racehorses after morning training at Jockey Club Brasileiro, $\mathrm{RJ}$, according to age.

\begin{tabular}{|c|c|c|c|c|c|c|c|}
\hline \multirow{2}{*}{ Age (years) } & \multirow{2}{*}{$\mathrm{n}$} & \multicolumn{6}{|c|}{ - } \\
\hline & & G0 & G1 & G2 & G3 & G4 & G5 \\
\hline 2 & 11 & 6 & 0 & 5 & 0 & 0 & 0 \\
\hline 3 & 22 & 17 & 4 & 1 & 0 & 0 & 0 \\
\hline 4 & 19 & 17 & 2 & 0 & 0 & 0 & 0 \\
\hline 5 & 13 & 10 & 2 & 1 & 0 & 0 & 0 \\
\hline \multirow[t]{2}{*}{6} & 7 & 6 & 0 & 1 & 0 & 0 & 0 \\
\hline & 72 & 56 & 8 & 8 & 0 & 0 & 0 \\
\hline
\end{tabular}

G0: grade 0; G1: grade1; G2: grade2; G3: grade 3; G4: grade 4; G5: grade 5, according to Gerber, 2004; $\mathrm{n}=$ number of horses.

(MICHELOTTO et al., 2010; FRELLSTEDT et al., 2015). Nearly $50 \%$ of the 2 -year-old horses in our study exhibited MSs of $2 / 5$ (Table 2). In previous reports, up to $73 \%$ of 2 -year-olds and $28 \%$ of 3 -yearolds had tracheal mucus accumulation (GERBER et al., 2003; CARDWELL et al., 2011; WYSOCKA \& KLUCINSKI, 2014), further supporting the possibility of adaptation. Increased mucus accumulation is likely to impact athletic performance, with tracheal mucus scores of 2 or greater being associated with poor performance (HOLCOMBE et al., 2006).

Of the 72 horses studied, 16 (22\%) had visible tracheal secretions, 8 (11\%) had $\mathrm{MS} \geq 2$, which can be considered a typical feature of IAD (HOLCOMBE et al., 2006; COÜETIL et al., 2016). Additionally, $13(18 \%)$ animals presented with carina edema, and $4(5 \%)$ presented simultaneously with $\mathrm{MS} \geq 2$ and carina edema. All horses with $\mathrm{MS} \geq 2$ demonstrated a $\Delta$ Pplmax higher than $4 \mathrm{~cm} \mathrm{H}_{2} \mathrm{O}$, indicating bronchospasm. Conversely, none of the 38 horses with normal interpleural pressure exhibited tracheal secretions on endoscopy. According to WYSOCKA \& KLUCINSKI (2014), the presence of tracheal mucus and carina edema on endoscopic examination are indicative of lower airway inflammation.

Statistical analysis demonstrated that there was a significant association $\left(\mathrm{P}=0.002, \chi^{2}=10.01\right)$ between elevated $\Delta$ Pplmax and a tracheal $\mathrm{MS} \geq 2$. The mean $\Delta$ Pplmax for horses diagnosed with $\mathrm{MS} \geq 2$ was $7.00 \pm 1.93$, while it was $4.88 \pm 1.32$ for horses with $\mathrm{MS}<2$. Using a two-sample $t$ test, this difference was significant $(\mathrm{P}=0.019,95 \% \mathrm{CI},-3.78-0.47)$. When $\Delta$ Pplmax values from horses with and without carina edema were compared, the difference was also statistically significant $(\mathrm{P}=0.033,95 \% \mathrm{CI},-1.93--0.01)$.
Overall, when single signs suggestive of IAD were considered, $47 \%(34 / 72)$ of the animals examined had abnormal $\Delta$ Pplmax, $18 \%(13 / 72)$ had a thickened carina, and $11 \%(8 / 72)$ had tracheal $M S \geq 2$. When the combination of results was investigated, $26.5 \%(8 / 34)$ had carina inflammation and abnormal $\Delta$ Pplmax, $23.5 \%(9 / 34)$ had tracheal $M S \geq 2$ and abnormal $\Delta$ Pplmax, and 50\% (4/8) had tracheal $\mathrm{MS} \geq 2$ and carina edema.

Transendoscopic tracheal aspiration and cytology were performed on the 16 horses that demonstrated tracheobronchial secretions with the purpose of evaluating cytological profiles, which revealed the following average percentages for cell counts: macrophages, $60.89 \pm 23.12$; neutrophils, $29.39 \pm 25.17$; lymphocytes, $8.50 \pm 7.68$; mast cells, $0.00 \pm 0.00$; and eosinophils, $1.22 \pm 0.97$. No universally accepted reference intervals exists for tracheal aspirate differential cell counts; however, CIAN et al. (2015) established the following means \pm standard deviations in asymptomatic horses: macrophages, 79.6 \pm 8.2 ; neutrophils, $9.3 \pm 5.8$; lymphocytes, $9.3 \pm 4.9$; mast cells, $0.0 \pm 0.0$; and eosinophils, $0.2 \pm 0.6$. Except for neutrophils, the cell populations appeared to be within these ranges (CIAN et al., 2015).

The percentage of neutrophils was greater than $20 \%$ in $61 \%$ of the slides examined, which could be indicative of airway inflammation (ROBINSON, 2003). Also, $90 \%$ of the animals with neutrophilia $(\geq 20 \%)$ showed abnormalities in both ventigraphy and endoscopy. Because only horses with tracheal mucus had cytology evaluated, no further analyses were pursued in order to not introduce bias into the analyses.

Although only $9(12 \%)$ of all the examined horses showed signs of EIPH on endoscopy, 94\% $(n=15)$ of the horses with tracheal secretions showed 
hemosiderophages, 44\% $(\mathrm{n}=7)$ showed hemosiderin, 94\% $(n=15)$ showed activated macrophages, and $75 \%$ $(n=12)$ showed epithelial cells on cytology. As the endoscopy was performed 60-90min after morning exercises (submaximal exercise), a low incidence of EIPH was expected. Presence of hemosiderophages was also expected because all horses were actively racing. SWEENEY et al. (1992) demonstrated that $86 \%$ of horses presented hemosiderophages on cytological evaluation of tracheal aspirate. According to DIXON (1997), the presence of hemosiderin within macrophages is a post-EIPH finding and rules out the possibility that erythrocytes or hemosiderin resulted from the trauma during the collection of samples.

Results of this study demonstrate high rates of non-infectious respiratory alterations, supporting research conducted in various countries that reported rates of $40 \%-80 \%$ of subclinical cases of respiratory disorders (GERBER et al., 2003; RAMZAN et al., 2008; KUSANO et al., 2008; WYSOCKA \& KLUCINSKI, 2014).

\section{CONCLUSION}

There is a high incidence of subclinical respiratory disorders in Thoroughbred horses trained at the Brazilian Jockey Club, especially in the 2-yearold ones, which reinforces the value of routine respiratory investigation in racehorses. Ancillary diagnostic tools such as ventigraphy, endoscopy, and tracheal aspirate cytology were useful for the diagnosis of subclinical respiratory conditions, including signs suggestive of IAD, and a significant association between a tracheal mucus score $\geq 2$, carina edema, and elevated $\Delta$ Pplmax exists.

\section{BIOETHICS AND BIOSSECURITY COMMITTEE APPROVAL}

We authors of the article entitled "Investigation of respiratory disorders in thoroughbred racehorses training at the Brazilian Jockey Club" declared, for all due purposes, the project that gave rise to the present data of the same has not been submitted for evaluation to the Ethics Committee of the Universidade Federal Fluminense (UFF), but we are aware of the content of the Brazilian resolutions of the Conselho Nacional de Controle de Experimentação Animal (CONCEA) < http://www.mct.gov.br/ index.php/content/view/310553.html $>$ if it involves animals.

Thus, the authors assume full responsibility for the presented data and are available for possible questions, should they be required by the competent authorities.

\section{REFERENCES}

AINSWORTH, D.M. et al. Recurrent airway obstruction (RAO) in horses is characterized by IFN gamma and IL- 8 production in bronchoalveolar lavage cells. Veterinary Immunology Immunopathology, v.96, p.83-91, 2003. Available from: <https:// www.ncbi.nlm.nih.gov/pubmed/14522137>. Accessed: Nov. 16, 2014. doi: 10.1016/S0165-2427(03)00142-9.

BEECH, J. Chronic obstructive pulmonary disease. Veterinary Clinics of North America: Equine Practice, INSS 0749-0739/91, v.7, n.1, p.79-91, 1991.

BOERMA, S. et al. Intrathoracic pressure in the horse. Correlation between intrapleural and esophageal pressures. Lung function and respiratory diseases in the horse, International Symposium, Hannover, June 27-29, p.49-51, 1985.

CARDWELL J.M. et al. Descriptive results from a longitudinal study of airway inflammation in British National Hunt racehorses. Equine Veterinary Journal, v.43, p.750755, 2011. Available from: <https://www.ncbi.nlm.nih. gov/pubmed/21496098>. Accessed: Oct. 18, 2014. doi: 10.1111/j.2042-3306.2010.00338.x.

CIAN, F. et al. Cytology of the lower respiratory tract in horses: an updated review. Equine Veterinary Education, v, 27(10), p.544555, 2015. Available from: <http://onlinelibrary.wiley.com>. Accessed: Feb. 21, 2016. doi: 10.1111/eve.12376.

COWELL, R.D. et al. Cytology and hematology of the horse. Goleta: American Veterinary Publications, 1992. Cap 5, p.1-19.

COUETIL, L.L. et al. Inflammatory airway disease of horses revised consensus statement. Journal of Veterinary Internal Medicine, v.30, n.2, p. 503-515, 2016. Available from: <https:// www.ncbi.nlm.nih.gov/pmc/articles/PMC4913592/>. Accessed: Jun. 3, 2016. doi: 10.1111/jvim. 13824 .

DIXON, P.M. Ancillary diagnostic techniques for the investigation of equine pulmonary disease. Equine Veterinary Education, v.9, n.2, p.72-80, 1997. Available from: <http://onlinelibrary.wiley. com>. Accessed: Mar. 23, 2015. doi: 10.1111/j.2042-3292.1997. tb01281.x.

FRELLSTEDT, L. et al. The innate immune response of equine bronchial epithelial cells is altered by training. Veterinary Research, v.46, n.3, p.46, 2015. Available from: <http:// pubmedcentralcanada.ca/pmcc/articles/PMC4297379/>. Accessed: Dec. 1, 2015. doi: 10.1186/s13567-014-0126-3.

GERBER, V. et al. Airway inflammation and mucus in two age groups of asymptomatic well-performing sport horses. Equine Veterinary Journal, v.35, n.5, p.491-495, 2003. Available from: $<$ https://www.ncbi.nlm.nih.gov/pubmed/12875328>. Accessed: Nov. 16, 2014 doi: 10.2746/042516403775600424.

GERBER, V. et al. Endoscopic scoring of mucus quantity and quality: observer and horse variance and relationship to inflammation, mucus viscoelasticity and volume. Equine Veterinary Journal, v.36, p.576-582, 2004. Available from: $<$ https://www.ncbi.nlm.nih.gov/pubmed/15581321> Accessed: Nov. 16, 2014. doi: 10.2746/0425164044864525.

HERHOLZ, C. et al. Relationship between clinical signs and pulmonary function estimated by the single breath diagram for $\mathrm{CO}(2)$ (SBD-CO(2) in horses with chronic obstructive pulmonary disease. Veterinary Journal, v.163, p.187-195, 2002. Available from: <https://doi.org/10.1053/tvj1.2001.0646>. Accessed: Oct. 7, 2014. doi: $10.1053 /$ tvj1.2001.0646. 
HOLCOMBE, S.J. et al. Effect of tracheal mucus and tracheal cytology on racing performance in Thoroughbred racehorses. Equine Veterinary Journal, v.38, n.4, p.300-304, 2006. Available from: <https://www.ncbi.nlm.nih.gov/pubmed/16866195>. Accessed: Nov. 16, 2014. doi: 10.2746/042516406777749191.

KLEIN, H.J.; DEEGEN, E. Die interpleurale drunkmessungeine methode zur beurteilung der lungen- funktion beim pfred. Pferdheilkunde, n.3, p.141-147, 1987. Available from: <http:// www.pferdeheilkunde.de/en/home-en/>. Accessed: Mar. 2, 2014.

KUSANO, K. et al. Tracheal endoscopic and cytological findings and blood examination results in thoroughbred racehorses suspected to have lower respiratory tract disease. Journal of Equine Science, v.19, n.4, p.97-102, 2008. Available from: $<$ https://www.ncbi.nlm.nih.gov/pmc/articles/PMC4013951/>. Accessed: Feb. 21, 2015. doi: 10.1294/jes.19.97.

MICHELOTTO JR. P.V. et al. Platelet-activating factor and evidence of oxidative stress in the bronchoalveolar fluid of Thoroughbred colts during race training. Journal of Veterinary Internal Medicine, v.24, p.414-419, 2010. Available from: $<$ https:/www.ncbi.nlm.nih.gov/pubmed/20102491>. Accessed: Jan. 3, 2014. doi: 10.1111/j.1939-1676.2010.0459.x.

PASCOE J.R. et al. Exercise-induced pulmonary haemorrhage in racing thoroughbreds: a preliminary study. American Journal of obstructive Research, v.42, n.5, p.703-707, 1981. Available from: <https://www.ncbi.nlm.nih.gov/pubmed/7258791>. Accessed: Jan. 3, 2014.

PEARSON, W. et al. Pilot study investigating the ability of an herbal composite to alleviate clinical signs of respiratory dysfunction in horses with recurrent airway obstruction. Canadian Journal of Veterinary Research, v.71, p.145-151, 2007. Available from: <https://www.ncbi. nlm.nih.gov/pmc/articles/PMC1829186/>. Accessed: Oct. 7, 2014.

RAMZAN, P.H.L. et al. Lower respiratory tract disease in Thoroughbred racehorses: analysis of endoscopic data from a UK training yard. Equine Veterinary Journal, v.40, n.1, p.7-13, 2008. Available from: <https://www.ncbi.nlm.nih.gov/pubmed/18083654>. Accessed: Jan. 21, 2014. doi: 10.2746/042516407X241059.

SWEENEY, C.R. et al. Cytolologic findings of tracheobronchial aspirates from 66 Thoroughbred racehorses. American Journal of Veteterinary Research, v.53, p.1172-1175, 1992. Available from: $<$ https://www.ncbi.nlm.nih.gov/pubmed/1497188>. Accessed: Feb. 21, 2014

WYSOCKA, B.; KLUCINSKI, W. Usefulness of the assessment of discharge accumulation in the lower airways and tracheal septum thickening in the differential diagnosis of recurrent airway obstruction (RAO) and inflammatory airway diseases (IAD) in the horse. Polish Journal of Veterinary Science, v.17-24, n.2, p.247-53, 2014. Available from: <https://www.ncbi.nlm.nih.gov/pubmed/24988850>. Accessed: Jan. 3, 2015. doi: 10.2478/pjvs-2014-0035. 